\title{
The Impact of Schools and Families in the Religions Perceptions of Children in Albania and Kosovo
}

\author{
Rita Loloçi \\ Faculty of Education, University “Aleksandër Moisiu” of Durrës, Albania \\ Menada Petro \\ Faculty of Education, University “Aleksandër Moisiu” of Durrës, Albania
}

\section{Abstract}

This study aimed to identify children`s perceptions regarding the role of religion in their education, their religious belonging, the parent's role in their religious education, and the attitude they have towards other religions. To gather quantitative data regarding the opinion the 10-14 age children have on religion and religious education, a survey was performed in several schools in Albania and Kosovo urban and rural areas $(720$ students from 8 schools of Durres, 4 in rural areas, and 473 students from 8 schools of Pristina and the surrounding area). A questionnaire was used to fulfill the purpose of the research regarding the knowledge, attitudes, and the perceptions of 10-14 age group on religious education in schools. At the same time, studies of national and international authors were consulted for a better analysis of the problems raised in the questionnaires such as the role and the importance of intercultural education in the coexistence and the harmony between people of different cultures, the education on The Fundamental Rights, the role of the curricula in schools, the difference between families in the rural and urban areas and the effect of the parents' education on children. The results of the study showed that children of this age group receive the first knowledge about religion from the family. An irreplaceable role in religious education has the media. The school involvement in giving knowledge on religious beliefs in both studied regions will positively influence pupil's formation, eliminating this way the violation of other people religion that often is present in our schools and not only. A correlation between the tolerance of parents and the tolerance of their children resulted as the consequence of the care that families show to respect different religions and often even sects.

Keywords: religion, school, belief, teacher, students, tolerance 


\section{Introduction}

The freedom of expressing religious beliefs and conscience has been sanctioned in international conventions, European as well as in Albanian legislation. It constitutes the foundations of a democratic society (Article 9 of The European Convention of the Human Rights and Fundamental Freedoms, ratified by the Albanian Parlament on July $31^{\text {st }}$ affirms that "There is no official religion in the Republic of Albania. 2. The state is impartial regarding the issues of religion and conscience and guarantees their free expression in public life. 3. The state recognizes the equality of religious communities").

We live in a global world wehere each of us has his/her own area of action and collaboration with others. In order for this global coexistence to function, it needs that everyone regardless of religion, sex, age or social status, has the knowledge, the ability, and the competencies to make it possible. For a period of 50 years, religious beliefs were forbidden in Albania (Article 37 of The Constitution of 1976 affirms that "The state does not recognize any religion and supports and develops atheist propaganda to root in people the scientific materialism outlook"). During the totalitarian communist regime, everyone who preached religion was prosecuted, the cult objects were destroyed and those that were left were converted into stables for the livestock, at the same time the frescoes, paintings and sculptures dedicated to God were destroyed, those who believed in a certain religion were prosecuted and as consequences atheism was propagandized. The functioning of religious institutions and religious beliefs was prohibited by law. This influenced the gradual lost of believing in God by the majority of the population. (UNDP and IDM, 2018), especially in the young generations, who did not have any information and did not have any source of knowledge about the religious beliefs. For this reason, most Albanians lead a laic life.

Currently, Albania is a country with positive practices regarding religious coexistence and religious tolerance. In Albania four official religions have been registered, Muslim, Orthodox, Catholic, and Evangelical (INSTAT, 2011). 
Table 1: Religios affiliation in Albania, (INSTAT, 2011)

\begin{tabular}{|l|l|l|l|l|}
\hline \multicolumn{4}{|l|}{ Albania } & Kosovo \\
\hline $\begin{array}{l}\text { Religious } \\
\text { affiliation }\end{array}$ & $\begin{array}{l}\text { Resident } \\
\text { population }\end{array}$ & $\begin{array}{l}\text { \% of } \\
\text { resident } \\
\text { population }\end{array}$ & $\begin{array}{l}\text { Resident } \\
\text { population }\end{array}$ & $\begin{array}{l}\text { \% of resident } \\
\text { population }\end{array}$ \\
\hline Total & 2.800 .138 & 100 & $1,739,825$ & 100 \\
\hline Muslims & 1.587 .608 & 56,70 & $1,663,412$ & 95.6 \\
\hline Bektashi & 58,628 & 2,09 & & \\
\hline Catholics & 280,921 & 10,03 & 38,438 & 2.2 \\
\hline Orthodox & 188,992 & 6,75 & 25,837 & 1.4 \\
\hline Evangelists & 3,797 & 0,14 & & \\
\hline Other Christians & 1,919 & 0,07 & & 0,072 \\
\hline $\begin{array}{l}\text { Believers without } \\
\text { denomination* }\end{array}$ & 153.63 & 5,49 & 1,242 & \\
\hline Atheists & 69,995 & 2,50 & & 0,07 \\
\hline Others & 602 & 0,02 & 1,188 & 0,42 \\
\hline $\begin{array}{l}\text { Prefer not to } \\
\text { answer }\end{array}$ & 386,024 & 13,79 & 7,213 & 0,14 \\
\hline $\begin{array}{l}\text { Not relevant/not } \\
\text { stated }\end{array}$ & 68,022 & 2,43 & 2,495 & \\
\hline
\end{tabular}

Having this variety in religions, Albanians have been careful to preserve social cohesion, harmony, and religious coexistence. For a long time, it was thought that the economic growth of society would reduce the impact of religion on social life. However, the last decade showed that different religions have been activated in society in another form and the world is facing violent religious extremism.

Religious education at a low level can significantly influence the instrumentalization of religious differences for political purposes. (Sinani, 2017).

The low economical level, the lack of religious education, the blind acceptance because of family religious belonging, made it possible that a considerable part of the youth to be used for political purposes. The misuse of religion and of the believers for political reasons reflects the need for the engagement of all institutions, parents, schools, NGO's, researchers, of all the society for the human rights education, in order to give children according to their age, specific knowledge on religions and their role in society, on religious tolerance and the need for social coexistence, where respec for each other is of primary importance.

Today we live in digital times, where social media are being massively used by all people. The youth is dealing with a chaos of information received in a digital way, without using filters of critical or scientific character, which can affect negatively their understanding of the world in general and in the role of religion in particular. Gaining knowledge about religion through the certified curricula at school enables students to acquire this knowledge through critical thinking, decrease curiosity about the 
unknown that now becomes known, not relativizing the phenomena and not accepting hate language, by affecting negatively in their civic education.

"Educating the youngsters to think critically helps in preventing extremism" (Schwandner-Sievers, 2016).

Being a country, which aspires to become part of the EU, Albania is oriented and follows its directives for religious education in public schools. This is reflected in recommendation 1720, point 6 approved on October $4^{\text {th, }} 2005$ by the European Parliament of EU which declares that: "Education is fundamental to fight ignorance, stereotypes and the misunderstanding of religions".

For a long time believing in religion has had a positive role. This role has been greater in harmonizing social relationships. The freedom of religious beliefs is a constitutional right protected by the state and as a result, it is the duty of the state institutions to take care of the righteous understanding of the role of religion and not to allow its misuse.

Albania is a country where the constitution affirms that there is no official religion, however, the constitution guarantees religious freedoms, Article 24/2 of the Constitution of the Republic of Albania (1998) affirms that "Everyone is free to choose or change religion or beliefs, as well as to show them individually or collectively, in public or in his private life, through cults, education, practices or rituals".

Particular attention has been shown by the state institution in order to not discriminate their citizens for their religious belonging or beliefs.

The principle of religious coexistence takes special value currently when the world is facing the danger of religious extremism, the imposition of elite beliefs in every way, through force, psychological, economical and political pressure. Using children for terrorist purposes under the disguisement of religious beliefs is a new form of war against extremist groups.

Even in Kosovo the freedom of religion is one of the fundamental human rights and one of the principles, and standards internationally accepted on freedom of speech, conscience and religious belonging, sanctioned by the law no 02/L-32, 2007 "On freedom of religion in Kosovo".

\section{Literature review}

The data gathered by the questions on the questionnaires aim to identify perceptions of the students of the age group 10-14 on the religious education in schools, and for this, we referred to some previous studies in this field. The study of literature in this article has been focused on a better analysis of the problems raised in the questionnaires such as the role and the importance of intercultural education in the coexistence and the harmony between people of different cultures, the education on the Fundamental Rights, the role of the curricula in schools, the difference between families in the rural and urban areas and the effect of the parents' education on 
children. Are the teachers ready to teach curricula on the role of religion in the righteous education of the children?

Hoppes (1981) and Bennet (1986) were referred to in order to explain the role of intercultural education in the creation of the religious identity and the creation of the right perceptions of religion. According to Hoppes (1981) and Bennett (1986), communication and interaction between people with cultural differences go through six stages. Knowing them helps in overcoming ethnocentric attitudes, in accepting the cultural difference and in the existence of different cultural forms, by making it possible for people to be able to understand and act beyond their cultural boundaries.

Educating children with human rights is very important to better explain and acquire knowledge about religion. The civic education of children is an important mission of all the actors that influence this education. The school, as an important institution, has a special role. The creation of children's identity is an important dimension for the creation of active citizenship with an ethical and legal approach.

By studying the importance of gaining the correct knowledge on religions by the children of this age group, it is claimed that even the way of forming their religious identity has fewer chances to be deformed and manipulated in the future (the theory of identity formation, the theory of social learning by engaging all the structures that take part in children education starting by the parent,s role model, the teacher,s role models and the positive or negative models in different social circles where the children are part of). The family has a considerable influence on the creation of religious identity. Referring to Bader and Desmond (2006), the parents model has an influence on the children when the quality of this relationship is a good one.

Even the training of critical thinking helps children to deepen their knowledge about different religions by helping them to better understand "the group pressure" (Facione, 2007), and to use logic and logical reasoning in those cases when they doubt that a statement about religion is in conflict with their knowledge although the community where they live is in majority compared to another religion. It is known that in the digital era it is easy to come across unreliable information, which is beautifully embellished in a provocative way so that they can catch the children's imagination.

\section{Methodology}

This study aims to identify some of the perceptions children have, students aged 1014 , regarding the role of religion in their education, their religious belonging, the parent's role in their religious education, and the attitude they have towards other religions. At the same time, this study aims to analyze the role of the school in the religious education of the generations and in fulfilling their needs for scientific knowledge about religion.

The questions in the questionnaire were closed with three alternatives Yes, No, No answer. To avoid any misunderstanding of the questions by the students and to 
correctly fill it in, we trained the teachers whose students completed the questionary. At the same time, studies of national and international authors were consulted and relevant literature on this topic was considered in order to make a clear and correct analysis. The study ethics stand in fact that the students were free in the way they would answer, the questionnaires were anonymous and it was explained that the data would be used only for study purposes.

In this study,720 students from 8 schools of Durres (4 in rural areas) and 473 students from 8 schools of Pristina and the surrounding area were included. These two regions were selected because Pristina is the capital of Kosovo with a heterogeneous population and with the largest population and Durres, a coastal city, is the second-largest city after Tirana regarding the number of population and its heterogeneity. The reason why this study sample was chosen, was to compare perceptions of this age group who belong to urban, rural areas and to families with different social statuses.

The questions addressed to the respondents were created to get as much data as possible, which would help to better explain the topic under consideration. The question of what education parents have been asked to see how much parental education influences the formation of religious beliefs in school students. Similarly, with the question of whether students believe in God or not, a direct opinion was sought on the degree of religious belief for the target group taken in the study. The question of whether students are practitioners of religion aims to obtain data on the differences in numbers between students, who believe in God and those who practice it regularly in the respective institutions. It is known that students have knowledge about religions, but is this knowledge accurate, what impact do schools, teachers, and other educational-cultural institutions have on basic religious education. Why school should have an important role in religious education? Since the school works with approved curricula, designed by specialists in the field who are subject to constant monitoring, it enables more accurate training in religious education by eliminating the abuses and misconduct of religion. Some of the survey questions sought to get concrete answers to cases of religious abuse, although Albanian society, including school students, has an admirable tolerance.

Albania, after the 90s, has known a disorganized inner migration, where many families moved from remote mountainous regions in the South and North towards Central Albania. Durres, as a coastal city, was mainly populated by people coming from the North of Albania, especially from its outskirts. This situation of cultural variety is reflected in the students' responses as well. 
Table 2: The matrix of the inner migration in Durres, (INSTAT 2011)

\begin{tabular}{|c|c|c|c|c|c|c|c|c|c|c|c|c|}
\hline & 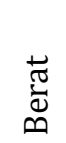 & $\begin{array}{l}\grave{d} \\
\stackrel{0}{0}\end{array}$ & 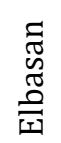 & 㐫 & 汽 & $\begin{array}{l}0 \\
0 \\
0 \\
01\end{array}$ & $\begin{array}{l}\mathscr{d} \\
\frac{y}{J} \\
\underline{y}\end{array}$ & 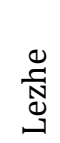 & 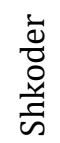 & 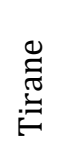 & 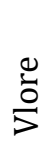 & $\stackrel{\overrightarrow{0}}{\ominus}$ \\
\hline Dur & 3.0 & 10. & 4.7 & 2.0 & 1.0 & 2.0 & 3.6 & 2.1 & 1.9 & 2.7 & 3 & 34. \\
\hline res & 98 & 064 & 72 & 45 & 66 & 55 & 49 & 60 & 78 & 91 & $\begin{array}{l}8 \\
1\end{array}$ & 059 \\
\hline
\end{tabular}

The sample of parents in the Durres region was made of 86\% Muslim religion, 8.3\% Catholic, 4\% Orthodox 1.7\% other religions. While in Pristina Region 91\% are muslims, $5.4 \%$ catholic, $2.2 \%$ orthodox and $0.3 \%$ other religions.

The muslim majority comes naturally because this community continues to be the largest in Albania and Kosovo and it is explained by the 500 years of rule that the Ottoman Empire had on these regions.

Despite this muslim majority, Albanians are invested by highlighting positive examples that Albanians have given throughout centuries for the European civilization.

After the Kosovo war and its independence there have been revived even two other communities: the catholic and the orthodox one which is in minority, this enabled by the opportunity that the law for religious freedom gives, but at the same time by the culture that Albanian people have inherited, which has valued more the nation than the religion. The religion of Albanians is Albania itself.

The general rule is that students follow the religion of their parents, but there are cases when they follow even other religions. Thus, even though they have Muslim parents, some students because of the foreign languages they have learned, especially English prefer to follow Christian practices, and even to get baptized. In this case, they use religion to learn a foreign language.

Thus, 5.4\% of the surveyed feel closer to the catholic religion, $92.1 \%$ to the Muslim religion, $2.2 \%$ to the orthodox religion and $0.3 \%$ to other religions.

The three religions in Albania have knowledge about other religions, and this originates from the inheritance of the National Renaissance which emphasized more the fact of being Albanians than the religion (UNDP, 2018).

\section{Results}

Table 3: The questionnaires questions and answers 


\begin{tabular}{|c|c|c|c|c|c|}
\hline \multirow{2}{*}{$\begin{array}{l}\text { Studied } \\
\text { area }\end{array}$} & \multirow[t]{2}{*}{ Questions } & \multicolumn{4}{|l|}{ Responses } \\
\hline & & $\begin{array}{l}\text { Catholic } \\
(\%)\end{array}$ & $\begin{array}{l}\text { Muslim } \\
(\%)\end{array}$ & $\begin{array}{l}\text { Orthodox } \\
(\%)\end{array}$ & $\begin{array}{l}\text { Others } \\
(\%)\end{array}$ \\
\hline $\begin{array}{l}\text { Durres } \\
\text { city } \\
\text { (Albania) }\end{array}$ & $\begin{array}{l}\text { [2] What religion do your parents } \\
\text { belong to? }\end{array}$ & 8.3 & 86 & 4 & 1.7 \\
\hline $\begin{array}{l}\text { Pristina } \\
\text { (Kosovo) }\end{array}$ & $\begin{array}{l}\text { [2] What religion do your parents } \\
\text { belong to? }\end{array}$ & 5.4 & 92.1 & 2.2 & 0.3 \\
\hline $\begin{array}{l}\text { Durres } \\
\text { city } \\
\text { (Albania) }\end{array}$ & $\begin{array}{l}\text { [2] Which religious faith do you } \\
\text { feel closest to? }\end{array}$ & 8.3 & 86 & 4 & 1.7 \\
\hline \multirow[t]{2}{*}{$\begin{array}{l}\begin{array}{l}\text { Pristina } \\
\text { (Kosovo) }\end{array} \\
\end{array}$} & $\begin{array}{l}\text { [2] Which religious faith do you } \\
\text { feel closest to? }\end{array}$ & 5.4 & 92.1 & 2.2 & 0.3 \\
\hline & & $\begin{array}{l}\text { Once/month } \\
\text { (\%) }\end{array}$ & $\begin{array}{l}\text { Twice/year } \\
(\%)\end{array}$ & $\begin{array}{l}\text { Many } \\
\text { times } \\
(\%)\end{array}$ & $\begin{array}{l}\text { Ever } \\
(\%)\end{array}$ \\
\hline $\begin{array}{l}\text { Durres } \\
\text { city } \\
\text { (Albania) }\end{array}$ & $\begin{array}{l}\text { [3] How often (times per week, } \\
\text { month or year) do you go to the } \\
\text { mosque or church? }\end{array}$ & 25 & 12 & 32 & 31 \\
\hline \multirow[t]{2}{*}{$\begin{array}{l}\text { Pristina } \\
\text { (Kosovo) }\end{array}$} & $\begin{array}{l}\text { [3] How often (times per week, } \\
\text { month, or year) do you go to the } \\
\text { mosque or church? }\end{array}$ & 15 & 28 & 36 & 21 \\
\hline & & Yes (\%) & No (\%) & \multicolumn{2}{|c|}{ Any time (\%) } \\
\hline $\begin{array}{l}\text { Durres } \\
\text { city } \\
\text { (Albania) }\end{array}$ & [1] Do you believe in God & $98.3 \%$ & 1.7 & \multicolumn{2}{|c|}{-} \\
\hline $\begin{array}{l}\text { Pristina } \\
\text { (Kosovo) }\end{array}$ & [1] Do you believe in God & $92 \%$ & 8 & \multicolumn{2}{|l|}{ - } \\
\hline $\begin{array}{l}\text { Durres } \\
\text { city } \\
\text { (Albania) }\end{array}$ & $\begin{array}{l}\text { [4] Do your parents talk to you } \\
\text { about religion? }\end{array}$ & 70.1 & 20,9 & \multicolumn{2}{|l|}{9} \\
\hline $\begin{array}{l}\text { Pristina } \\
\text { (Kosovo) }\end{array}$ & $\begin{array}{l}\text { [4] Do your parents talk to you } \\
\text { about religion? }\end{array}$ & 64.4 & 17 & \multicolumn{2}{|l|}{18.6} \\
\hline $\begin{array}{l}\text { Durres } \\
\text { city } \\
\text { (Albania }\end{array}$ & $\begin{array}{l}\text { [5] Do teachers give information } \\
\text { or knowledge about religions? }\end{array}$ & 36,3 & 56,7 & \multicolumn{2}{|l|}{7} \\
\hline $\begin{array}{l}\text { Pristina } \\
\text { (Kosovo) }\end{array}$ & $\begin{array}{l}\text { [5] Do teachers give information } \\
\text { or knowledge about religions? }\end{array}$ & 24.3 & 60.7 & \multicolumn{2}{|l|}{15} \\
\hline $\begin{array}{l}\text { Durres } \\
\text { city } \\
\text { (Albania) }\end{array}$ & $\begin{array}{l}\text { [6] Do you think you have enough } \\
\text { knowledge about religion? }\end{array}$ & 35,8 & 54.6 & \multicolumn{2}{|l|}{9.6} \\
\hline $\begin{array}{l}\text { Pristina } \\
\text { (Kosovo) }\end{array}$ & $\begin{array}{l}\text { [6] Do you think you have enough } \\
\text { knowledge about religion? }\end{array}$ & 25.4 & 44.6 & \multicolumn{2}{|l|}{30} \\
\hline $\begin{array}{l}\text { Durres } \\
\text { city } \\
\text { (Albania) } \\
\end{array}$ & $\begin{array}{l}\text { [7] Do you think school should } \\
\text { educate you regarding } \\
\text { religion? }\end{array}$ & 60.7 & 39.3 & \multicolumn{2}{|l|}{-} \\
\hline $\begin{array}{l}\text { Pristina } \\
\text { (Kosovo) }\end{array}$ & $\begin{array}{l}\text { [7] Do you think school should } \\
\text { educate you regarding } \\
\text { religion? }\end{array}$ & 71.8 & 28.2 & \multicolumn{2}{|l|}{-} \\
\hline $\begin{array}{l}\text { Durres } \\
\text { city } \\
\text { (Albania) }\end{array}$ & $\begin{array}{l}\text { [8] Do you condemn those } \\
\text { who misuse religion? }\end{array}$ & 87.5 & 12.5 & \multicolumn{2}{|l|}{-} \\
\hline $\begin{array}{l}\text { Pristina } \\
\text { (Kosovo) }\end{array}$ & $\begin{array}{l}\text { [8] Do you condemn those } \\
\text { who misuse religion? }\end{array}$ & 91.7 & 8.3 & \multicolumn{2}{|l|}{ - } \\
\hline
\end{tabular}




\begin{tabular}{|l|l|l|l|l|l|}
\hline $\begin{array}{l}\text { Durres } \\
\text { city } \\
\text { (Albania) }\end{array}$ & $\begin{array}{l}\text { [9] Are you tolerant of } \\
\text { students of other faiths? }\end{array}$ & 86.1 & 5.6 & 8.3 \\
\hline $\begin{array}{l}\text { Pristina } \\
\text { (Kosovo) }\end{array}$ & $\begin{array}{l}\text { [9] Are you tolerant of } \\
\text { students of other faiths? }\end{array}$ & 71.4 & 11.8 & 16.8 \\
\hline $\begin{array}{l}\text { Durres } \\
\text { city } \\
\text { (Albania) }\end{array}$ & $\begin{array}{l}\text { [9] Do you have friends of } \\
\text { other faiths? }\end{array}$ & 79.3 & 10.7 & - & Others \\
\hline $\begin{array}{l}\text { Pristina } \\
\text { (Kosovo) }\end{array}$ & $\begin{array}{l}\text { [9] Do you have friends of } \\
\text { other faiths? }\end{array}$ & 53.6 & 46.3 & - & 10.7 \\
\hline $\begin{array}{l}\text { Durres } \\
\text { city } \\
\text { (Albania) }\end{array}$ & $\begin{array}{l}\text { [10] Where would you like to } \\
\text { learn about religion? }\end{array}$ & 44.4 & 17.8 & 27.1 & $\begin{array}{l}\text { Experts } \\
\text { (\%) }\end{array}$ \\
\hline $\begin{array}{l}\text { Pristina } \\
\text { (Kosovo) }\end{array}$ & $\begin{array}{l}\text { [10] Where would you like to } \\
\text { learn about religion? }\end{array}$ & 37 & 36 & 15,3 & 11.7 \\
\hline
\end{tabular}

\section{Discussion}

The population in this study was not selected randomly. As can be seen in the graph, $37.2 \%$ of the surveyed students live in the city, $14.2 \%$ live in small municipalities such as Shijak, while $48.9 \%$ of the surveyed live in rural areas. Most of the surveyed in the Durres region live in rural areas, which makes it possible to observe the tendency that this community has towards religion and religious faith.

In Kosovo, $34.6 \%$ of the surveyed live in the city of Pristina, while $65.4 \%$ live in the rural areas around Pristina.

The religious culture of the community in the suburbs is different from the attitude they have towards the local culture, which is in a process of continuous change.

The education in a patriarchal family mostly in the remote area, in the North or South of the country, have left a trace even in the big step that they had taken by moving in urban areas, hoping for a better life and realigns a dream which was categorically forbidden during the totalitarian system.

[1] From the questionnaries resulted that $98.3 \%$ of the students in Durres region believe in God. This happened after a radical transformation that the Albanian society went through. Although for a period of 50 years the communist regime in Albania destroyed religious institutions, imprisoned and killed some of the representatives of religions.

During the communist period, dictator Enver Hoxha conceived the fight against religion and religious beliefs under the propaganda of nationalism. Albania for 50 years was guided by the Marxist-Leninist ideology, the essence of which was the creating of an atheist state. According to the publicist Fatos Lubonja, Enver Hoxha 
constantly preached that Catholicism, Islamism, and Orthodoxy were foreign philosophies introduced to Albania by foreign elements, which in their essence threatened the integrity of the nation. For this reason, religious institutions, objects of worship had to be destroyed. The decision to destroy the religious cults was taken by an Ordinance with a top secret note, dated February 27, 1967 (Albanian Labor Party, Central Committee, no. 133, top -secret, Tirana, on 27. II. 1967), (Prifti. P 2017). After this date the Albanian communists banned all religious practices, closing numerous churches and mosques, and turning them into cinemas, sports halls, and bars-restaurants. In the ' 90 s the religion was returned, the religious institutions were rebuilt and the new clerics were prepared.

$92 \%$ of the students in the Pristina region believe in God, this is explained by the deep roots of faith, mostly muslims, which has existed and still exists in the Kosovo territory.

In contrast to Albania, that during the dictatorship proclaimed itself as the only atheist country in the world, Kosovo continued to follow religious rituals and education, but on the other side, there was a decrease in the catholic and orthodox religion that was helped by the Beograd's official politics to identify this population as only muslim.

The decline in the number of Kosovo Albanians was helped by the ethnic cleansing that was done in Kosovo by the Serbian Croatian Slovenian Kingdom and then these politics was followed by the Federal Republic of Yugoslavia under Milosevic, starting with the ethnical cleansing in 1878 till 1960 with the Rankovic massacres. (Sota, 2011).

In 1919-1937, 4046 Kosovo families moved from their lands and settled in Albania (Sota, 2011).

[2] When asked what faith your parents belong to and what faith you feel closest to, there is a kind of compatibility with the religious belief in the family in Albania and in Kosovo.

[3] $25 \%$ of the students in Albania follow religious rituals once a month, $32 \%$ many times, $12 \%$ twice a year and $31 \%$ do not frequent these institutions at all. As it can be seen by the responses there is a percentage almost equal, whereas $50 \%$ frequent these institutions, while $50 \%$ do not frequent at all or rarely frequent these institutions.

The responses to these questions might be explained by the tendency that children of this age group have to frequent religious institutions. There are two possible explanations in the interpretation of these data, one is related to the problem of financial difficulties that many families of these regions had after the fall of the dictatorship and the beginning of democracy. Since the government programs were unable to help them, they found help and support in the religious communities. Based on the religious document of Kuran, which among other things, talks about the help 
that should be given to poor and in need people, and in the religious ceremonies everyone shared something with others as an obligation towards God.

Another reason for the attendance in the religious institutions by this age group is the Albanian tradition to be together in different events and religious celebrations. While the surveyed in the region of Pristina, $15 \%$ follow religious rituals once a year, $28 \%$ twice a year, $36 \%$ many times and $21 \%$ do not frequent at all.

Even in Kosovo the tendency of frequenting the religious institutions is almost the same with their peers in Albania.

Even in Kosovo the religious belief is cultivated and inherited, not only by getting religious information at home by the parents, in religious institutions but also by exercising it with the massive attendance in mosques.

[4] 70.1\% of the surveyed in Durres region and 64.4\% in Pristina region talk with their parents about religious faith or religion in general and $20.9 \%$ in Durres region and $17 \%$ in Pristina region do not talk at all with their parents on this topic, $18.6 \%$ of the surveyed in Pristina region sometimes discuss with their parents. This is a result of the parents' awareness that care even for the religious education of their children.

Albanian parents (Bader, D. C. \& Desmond, A. S. 2006) have a tradition to teach their children religious rituals in addition to the general things a child should have. These rituals are naturally done at home, and children are even taught by what their parents do.

[5] 36.3\% students in Durres region and 24.3\% of students in Pristina region say that teachers and educators explain information on religion during the teaching process, $56.7 \%$ in Durres region and $60.7 \%$ in Pristina region say that teachers do not explain anything about religious issues and $7 \%$ in Durres region say that teachers sometimes explain religious issues.

As it can be seen, in both regions, teachers are limited and give information on religion only in cases when it is related to different topics of the school curricula. This is understood even by the fact that based on the legislation about pre-university education, schools are laic. The debate that has started in school and university circles on religious education, will necessarily leave a trace in the Albanian society of Kosovo.

[6] 35.8\% of students in Durres region and 25.4\% of students in Pristina region think they have enough knowledge on religion, while 9.6\% of them in Durres region and $30 \%$ in Pristina region think they have little information on religion and $54.6 \%$ in Durres region and $44.6 \%$ in Pristina region say that they have no information at all on religion. Students that have answered positively on enough knowledge about religion justify it by the great efforts that the religious communities make and by the specific schools they have.

Normally this knowledge often comes spontaneously since the religious teaching is not included in the curricula of the 9-year cycle. And the not-so-right opinion that sees 
religious teaching as a threat to exact knowledge and to the scientific formation of the students continues to be strong.

Most of the students take religious knowledge only from parents or those that are practitioners take it from religious services, and very rarely by civic education teachers.

This gap, if it is left uncovered risks that people who are not well informed about the religion of their parents or about other religions, can easily be deceived by different fundamentalists who have become a source for terrorist acts, but even for those that have an indifferent attitude towards such events that are mainly anti-religious.

[7] $60.7 \%$ of students in Durres region and $71.8 \%$ of students in Pristina region say that the school should give them more information on religion and religious beliefs, while $39.3 \%$ of the students in Durres region and $28.2 \%$ of students in Pristina region are against taking religious information in schools.

This response is related firstly to the open debate in the media and in media and academic circles on the role of schools in religious education. In this debate, there have been many opinions in favor and against it, they look at the acquisition of knowledge about religions by students through a collaboration between the religious communities, and the history teacher which is part of educational institutes.

However, as it can be seen by the students' responses, they want the school to get involved in conveying information on religions considering it an important factor in religious education. The experience of some European countries should be used even in this aspect by countries such as Kosovo that aspire to become part of this community.

This does not mean that parents and religious institutions should give up religious education, but the school involvement would be a factor more that would bring a different reality by becoming a barrier even against fundamentalist actions that happen time after time in every religious community.

[10] It is worth emphasizing that from the student's responses in the Durres region, it is noticed confusion because on one hand, $60.7 \%$ of them would like to receive religious information in school (Vikdahi, L. \& Skeie, G. 2019) and on the other hand, $44.4 \%$ of students want to receive this information by their parents and only $17.8 \%$ by their teachers $(27.1 \%$ by historians and $10.7 \%$ by others). The responses to these questions show in fact a reality that parents are the ones that talk more with their children and have more influence about faith and religions.

Whereas in the Pristina region, $36 \%$ of the surveyed have responded that they want to receive this information from teachers, $37 \%$ from their parents, $15.3 \%$ by historians and $11.7 \%$ by others.

Similar responses: teachers, parents, and historians, show that these are the three factors that influence their religious education. However, they should not be the only 
ones; even other factors can have a positive or a negative influence on them. In general, sociologists, psychologists, and intellectuals have a particular role, especially those of social sciences.

[8] Around 90\% of the surveyed in Albania and in Kosovo condemn people who misuse faith and religious beliefs. However, it is concerning the negative answer of $10 \%$ of students.

Most of the surveyed condemn the people who misuse the religious beliefs or that overestimate the religion they belong to and underestimate that of the others. There are a lot of cases when students have organized peaceful protests against specific cases of excesses of one religion against another.

Although not in a great number, there have been some negative phenomena. Both in Albania and in Kosovo there were deceived youngsters that took part in the war in Syria.

[9] Thus, $86.1 \%$ of students in the Durres region and $71.4 \%$ of students in the Pristina region are tolerant towards people who belong to other religions; a minority of the $5.6 \%$ in the Durres region and $11.8 \%$ in the Pristina region are not tolerant, $8.3 \%$ of students in Durres region and $16.8 \%$ in Pristina region are between being tolerant and intolerant. It should be seen with concern that almost $28.6 \%$ of the students in the Kosovo region have intolerant tendencies against other religions and in this aspect, there is a lot to be done firstly by the religious communities and by the families,

(Habermas. J,2008) without excluding the other factors that have an influence on religious culture.

Meanwhile, the religious tolerance in Albania is a sui generis quality of Albanians that is highly estimated even by the Western world. The Holy Father himself during the visit he held in Albania, emphasized the value of religious tolerance (Çabej, E.1999) as a value of the Albanian people's culture.

This majority in Durres is explained not only with the religious tolerance but even with the fact that many Albanian families have the same customs and traditions inherited in centuries and value good characteristics and are against those characteristics that damage them as a nation, as a state, or as a society.

Whereas the figure $46.3 \%$ in the region of Pristina can be explained with the fact that in Kosovo the Muslims make up around $96 \%$ of the population and only $4 \%$ belong to the Christian communities, so the probability to have a society with students of other religions is small.

\section{Conclusions}

In general, the results show that the primary religious knowledge of the students in this group age comes mainly from their families and the celebrations of the religious 
celebrations. This shows that they do not have deep knowledge of their religion or any other religion.

Also, it is noticed that the more they know about their religion, the more tolerant they are to have in their friendships with people of other religions. This shows that when parents and society are more open towards religious education brings a healthier youth, who is ready to accept in their friendships people from other religions keeping/conveying their faith precisely.

Ranking school in third place is at the same time an appeal that it should take a primary role in religious education, although from this education should not be excluded, anyone. The media also has an irreplaceable role in religious education.

The school involvement in giving knowledge on religious beliefs in general and those specific in Albania will positively influence pupil's formation, eliminating this way the violation of other people religion that often is present in our schools and not only.

There is a correlation between the tolerance of parents and the tolerance of their children as the consequence of the care that families show to respect different religions and often even sects.

\section{Recommendation}

The creation of the religious identity of children is considered an important process of personality. For this reason, it is recommended to deepen studies in this area. To pay attention to family and educational institutions the way children acquire knowledge about religions. Seeing the great role of the family in this process, it is recommended greater cooperation between the school and the parents. To prevent children from being misinformed with knowledge about religion, it is recommended that the school has accurate and scientific knowledge about religion in its curricula. Since we live in a global world of religious diversity, teachers and parents are required to be trained to respect the religious identity of others.

\section{References}

[1] Alexander, J. C. \& Seidman, S. (1994). Culture and Society. (Contemprorary debates), Cambridge University Press.

[2] Archer, M. S. (1998). Culture and Agency. The palace of culture in Social Theory, Cambridge University Press.

[3] Bader, D. C. \& Desmond, A. S. (2006). Do as I Say and as I Do: The Effects of Consistent Parental Beliefs and Behaviors upon Religious Transmission. Journal "Sociology of Religion, 67 (3), 313- 329

[4] Bennett, Milton, J. (1986). A Developmental Approach to Training for Intercultural Sensitivity, Research Gate.

[5] Charles. C, \& Haynes. (2004). A Teacher's Guide to Religion in the Public Schools, publisher, first amendment center.org. 
[6] Constitution of the Republic of Albania, amended by laws: No. 9675, dt. 13.01.2007, No. 9904, dt. 21.04.2008, No. 88/2012, dt. 18.09.2012, No. 137/2015, dt. 17.12.2015, No. 76/2016, dt. 22.07.2016, No. 115/2020, dt. 30.07.2020, Publication of the Center for Official Publications.

[7] Council of Europe Charter on Education for Democratic Citizenship and Human Rights. Adopted in the framework of Recommendation CM / Rec (2010) 7 of the Committee of Ministers.

[8] Çabej, E. (1999). Shqiptarët midis Perëndimit dhe Lindjes. Tiranë. Published by Albanian Academy of Sciences.

[9] Eco. U, (2007). Në kërkim të gjuhës së përkryer në kulturës evropiane. Published by "Dituria", Tirane, Albania.

[10] Fuga. A, (2016). Interviste edukimi mbi fete ne shkolle. "In the Temple" TV show of Anisa Ymeri. (C) News24 TV, 15 April 2016.

[11] Habermas. J, (2008). Midis natyralizmit dhe religjionit. Published by "Asdreni", Scopie, North Macedonia.

[12] IDM, (2015). Religious radicalism and violent extremism in Albania. The framework of the Project "Preventing religious radicalism among youth" financially supported by the US Embassy in Tirana.

[13] INSTAT, Retreived by: http://www.instat.gov.al/al/temat/censet/censusi-ipopullsis\%C3\%AB-dhe-banesave/\#tab2

[14] Jones. P, (1994). Bearing the Consequences of Belief". The Journal of Political Philosophy, 2, (1), $24-43$.

[15] Law No. 8137, dt. 31.07.1996. For the ratification of the European Convention for the Protection of Human Rights and Fundamental Freedoms.

[16] Law No. 5506, dt. 28.12.1976 of Constitution of the Socialist National Republic of Albania. Publication of the Center for Official Publications.

[17] Lubonja. F, (2011). Feja Dhe Shqiptaret, Perpjekja Magazine.

[18] Sinani. Gj, (2017). Feja dhe Edukimi, published by Albdesign, Tirane.

[19] UNDP, (2018). Religious tolerance in Albania. UNDP report.

[20] Sota, J. (2011). "Shpërngulja e shqiptarëve nga kosova e viset e tjera dhe trajtimi i tyre nga qeveritë e shqipërisë ndërmjet dy luftrave botërore", Journal of Institute Alb-Shkenca, ISSN 2073-2244 www.alb-shkenca.org

[21] Vikdahi, L. \& Skeie, G. (2019). Possibilities and limitations of religion-related dialog in schools. Issue 1: Possibilities and Limitations of Religion-Related Dialogue in Schools in Europe. Conclusion and discussion of findings from the ReDi project Religion \& Education, 46, 2019. 